\title{
Correlates and Issues of Academic Course-Selection in Post-Secondary Education in India: Evidence from National Sample Survey, 2007-08
}

\author{
Chandan Kumar ${ }^{*}$, S. P. Singh², D. K. Nauriyal² \\ ${ }^{1}$ Department of Geography, School of Earth Sciences, Central University of Karnataka, Gulbarga, India \\ ${ }^{2}$ Department of Humanities \& Social Sciences, Indian Institute of Technology Roorkee (IITR), Roorkee, India \\ Email: c.kumar803@gmail.com, singh fhs@iitr.ernet.in, dknar fhs@iitr.ernet.in
}

Received 12 April 2014; revised 21 May 2014; accepted 29 May 2014

Copyright (C) 2014 by authors and OALib.

This work is licensed under the Creative Commons Attribution International License (CC BY). http://creativecommons.org/licenses/by/4.0/

(c) (i) Open Access

\begin{abstract}
Background: With the rising educational unemployment in India, one can recognize the possibility of certain imbalance in the acquirement of tertiary education and the requirement of workforce in India. An assessment of youth's selection of their post-secondary courses could provide a layout for the effective planning of higher education with respect to the demand of workforce in the country. This study examines a set of individual/household, institutional, and regional factors influencing the selection of academic courses in post-secondary level education in India among the population aged 29 years and younger. Methods and Findings: The study is based on the information collected by the $64^{\text {th }}$ round of National Sample Survey (NSS) on "Participation and Expenditure in Education" in India during July 2007-June 2008. Using multivariate multinomial logistic regression model, the study shows that more than half of the total population aged $\leq 29$ years were likely to opt for Arts/Humanities courses while controlling for selected potential factors at their mean. However, approximately one in every five students had chance to opt for Science courses, and nearly $13 \%$ and $12 \%$ students were likely to choose Commerce and Technical/Professional/Vocational (TPV) courses respectively. The selection of academic courses was significantly different by a set of individual/household factors. The study also recommends ways to deal with the imbalance in course-selection based on research studies undertaken elsewhere. Conclusion: The major individual, household and institutional factors were found significant determinants of the choice of subject-course at post-secondary level in India, which can be persuaded to make a balance between the job-market requirements and the trained workforce in order to make plans for the use of available human resource effectively as a bonus.
\end{abstract}

\footnotetext{
${ }^{*}$ Corresponding author.
} 


\section{Keywords}

\section{Academic Course-Selection, Post-Secondary Education, Higher Education in India, National Sample Survey}

\section{Introduction}

South and West Asia are only next to sub-Saharan Africa in terms of the lowest tertiary (post-secondary) gross enrolment ratio (GER) in the world. India, however, with only 12\% (2007) of GER in the tertiary education, is considered as the world's third largest academic system in tertiary education after China and USA, which is growing rapidly and will continue to do so [1]. On the other hand, with rising levels of education, unemployment is mounting in the country [2] [3].

With the census projection report estimating the youth-population (aged 15 - 24 years) as high as 240 million by 2011, there has been much discussion and uncertainties about whether India would be able to take advantage of this surge of working age people (well referred as "Demographic Dividend") in the next few decades. There is a huge opportunity to fuel the rapidly growing economy with an army of educated youth and which can change the face of poverty-stricken India. However, although efforts are well intentioned and progress is made, massive challenges persevere and many feel that India is likely to miss the boat. For India to maintain its economic growth in a global marketplace fueled by the knowledge economy, it needs to augment its number of students in higher education [4]. More than half of India's population is under the age of 25. Without proper access to education, the country's demographic dividend might turn into a demographic disaster [4]. The main obstacle is an inadequate college system that churns out thousands of graduates without a job-oriented skills, which renders them unemployable [5]. As per the estimates from "Employment and Unemployment Survey 2012" conducted by the Labor Bureau under the Union ministry of labour and employment, the unemployment among graduates was $9.4 \%$ and among post-graduates it was $10 \%$, which is perhaps more than twice the unemployment rate for graduates in recession-hit countries like USA and UK [6]. The estimates were even higher for women, rural population, and socially backward castes. As per the 2004 estimates, out of 5.2 million educated unemployed in the country, the highest number was that of graduates and post-graduates in Arts subjects (over 2.1 million). This was followed by Science (over 1.0 million), Commerce (over 0.7 million) and Engineering (over 0.2 million). Those educated in Medicine and Veterinary science showed the lowest unemployment rate (about 50,000 and 7000 respectively). These figures were presented in reply to a question in Indian Parliament on the number of unemployed youth in the country [7]. However, this does not represent an unemployment rate, as the information on number of enrolled students by the subject course is missing. As per the National Science Survey $2004,12.6 \%$ population with post-secondary education in Science were unemployed compared to $10.1 \%$ in nonScience subjects [8], however these estimates mask the nature and status of (un)employment. There is no denying the fact that Science oriented subjects fetch better employment and wage prospects [9] compared to Arts/ Humanities subjects all across the world.

Several trainers and consultants opine that companies find it hard to employ educated youth even though there is a shortage of skilled work force because they lack communication skills, analytical skills and knowledge of their domains. The South Asian Voice (September 2005 edition) states that, "More small towns in India have more degree colleges than perhaps any other developing nation. However, unlike India, other developing nations do not waste precious academic resources on a dead-end degree such as a BA Pass."

The nature of the labor market in India is transforming from agricultural to non-agricultural, and unskilled to highly skilled, which renders the working age population to possess specific skills. However, the skill formation for the youth seems to be an outlying phenomenon so far, as about $90 \%$ youths in India were devoid of any kind of vocational training and among the rest, about one third had received through hereditary practices [2]. Similarly, a slightly more than $2 \%$ population (aged 15 years and above) had diploma/certificate/degree in technical education [2]. Moreover, the lack of the competent workforce is also attributed to the suboptimal quality of education, as according to the latest report by NASSCOM only $25 \%$ engineering graduates in India were employable. However, if India has to harness the productivity of the buoyant young workforce, there is a need to make a balance between the educational and employment orientation of the population. Now, the questions arise, 
why such imbalance comes about; what renders the young population to opt for general education and not for technical or vocational education? What are the factors, which determine the youths to select particular subject course after their secondary education? However, there are few studies in existing Indian literature, which could allow legitimate understanding over such inquiries. Even in general, the research on educational inequalities focuses on educational level, and does not acknowledge the importance of field of study or subject. However, the field of study affects many aspects of people's lives, such as labour market outcomes [10] [11], lifestyles [12], and political orientations [13] [14]. This study proposes a comprehensive framework for academic-course selection and examines a set of individual/household, institutional, and regional factors influencing the selection of academic courses in post-secondary level education in India among the population aged 29 years and younger. The study also figures out the socioeconomic disparities in the level of post-secondary education among the population aged $\geq 15$ years to provide a background before the subject-choice discussion.

\section{Conceptual Framework}

The subject-course selection or the college selection by students in their post-secondary level of education is a complex, multistage process during which an individual develops aspirations to continue formal education beyond high school, followed by a decision to attend a specific college/university/institution of advanced education and training [15], and then opt for a specific subject course. College or subject-choice is dependent upon an interactive set of factors involving student background characteristics and external influences, which include influential persons, institutional characteristics, and communication from institutions [16] [17]. Empirical studies and models based on factors of college choice can also be comprehended to understand the potential determinants of subject-choice by students at post-secondary level. James et al. (1999) document that the course of study decisions tend to be closely related to institutional choice decisions [18].

Of several college choice models of higher education and the opportunity to enroll in a single institution [19], the three-stage model of Hossler and Gallagher (1987) is the most simplified version and which combines all overlapping stages/aspects/processes [15]. This three-phase model has been the framework for many research studies surrounding the student choice process [19]-[21]. The model begins with the predisposition phase in which students "determine" whether to continue their education beyond high school. At this stage, student achievement and ability, level of educational aspiration, parental income, parental education, and parental encouragement are important influences [15] [16]. In the second phase, what they call the "search" phase, students gather information about institutions, decide to apply to certain schools, and are admitted. In the final stage of this model comes "choice", when the students decide on a particular college or university to attend. In context of students' subject choice, we can extend this model to a next phase where they get the opportunity to select their subject of study. However, the choice of subject sometimes may also determine the students' choice of particular college [18] or may be a simultaneous decision.

These phases of determination, search, and choice are destined to be influenced by a range of factors. Many studies on college student decision-making have used economic and sociologic theoretical frameworks to examine the factors of college choice [22]-[25]. The economic models focus on the econometric assumptions that prospective college students think rationally and make careful cost-benefit analyses when choosing a college [26]. The status-attainment models assume a utilitarian decision-making process that students go through in choosing a college, specifying a variety of social and individual factors leading to occupational and educational aspirations [27]. We can combine several such factors while assessing the subject-choice decisions made by individuals. Figure 1 presents a schematic diagram of potential determinants of subject-choice at higher education level. Based on the existing empirical and conceptual literature, we have framed several potential factors in four broad categories. These are individual characteristics, family background, psychosocial factors, and contextual determinants.

The individual characteristics include gender, age at entry in school, academic interest or personal ambition, previous academic performance etc. An adequate number of studies conclude that when young people explain their reasons for their educational choice, they emphasize personal interest ([28]-[31], cited in [32]). Several interest studies in science education show that girls' and boys' interests are different ([33]-[38], cited in [32]). A few studies have also explored gender differences in young people's reasons for their post-16 subject choices in relation to the study of mathematics and/or science subjects [39]-[45]. On a general level, the findings suggest that girls are more interested in issues to do with human health and well-being, whereas boys are more interested 


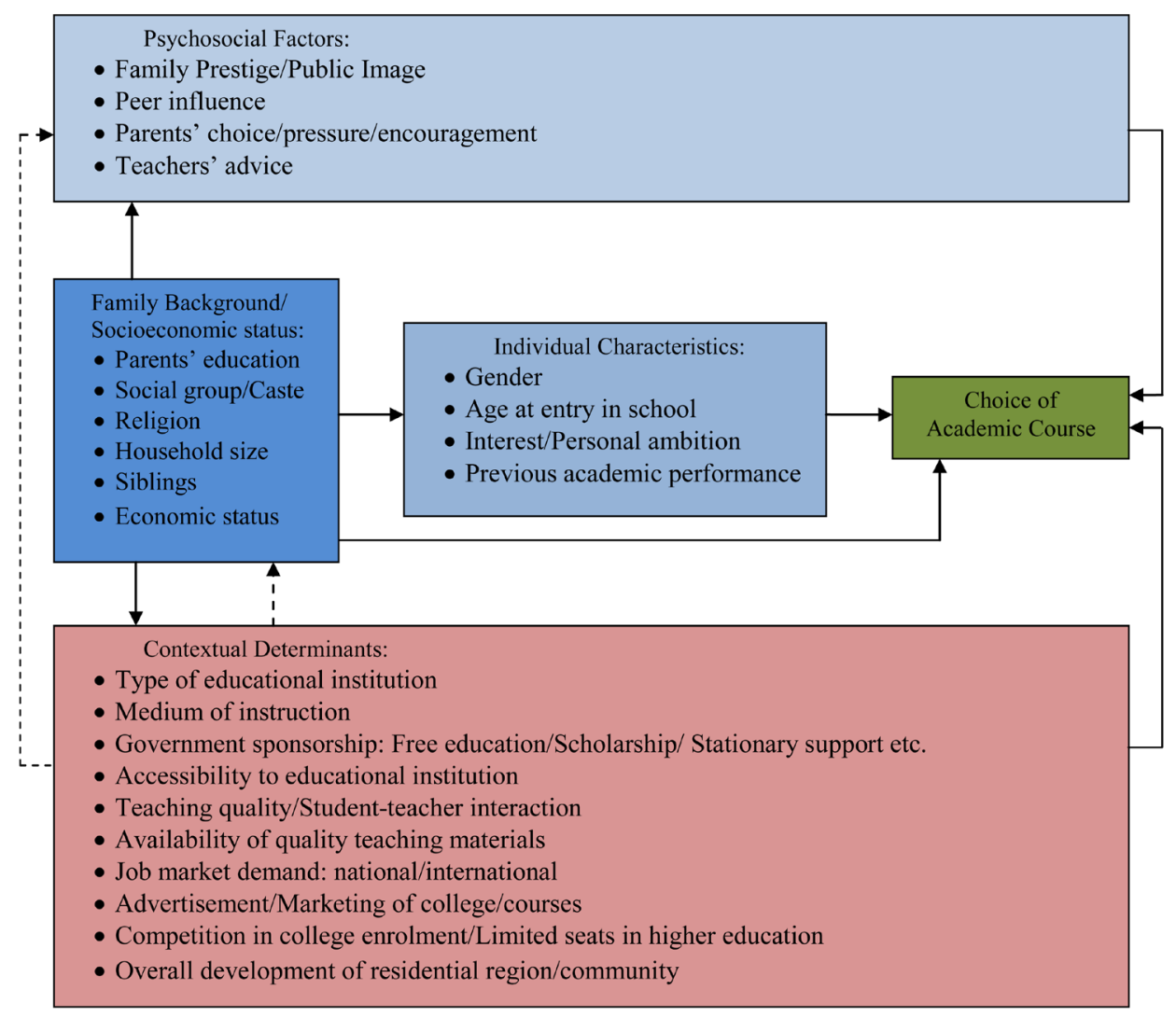

Figure 1. A conceptual framework illustrating potential determinants of the choice of academic course in higher education.

in things to do with e.g. science and technology. One's perception of one's own abilities and qualifications is reported as important for educational choice. While girls in general outperform boys in many school subjects, boys do better than girls in a number of science/technology/mathematics subjects, and girls express less selfconfidence in such subjects [46]. An empirical study based on German students [47] found that boys' physicsrelated self-concept was higher than their general school-related self-concept, whereas it was in contrast for girls. Bandura et al. (2001) have pointed to young people's self-efficacy beliefs as important determinants of educational aspirations and career trajectories [48]. The educational achievement is also found to be influencing in selection of educational institution [23] [49]-[51], and thus likely to affect the individuals' decision on opting for particular stream of study.

Family background or the socioeconomic characteristics of the students play a major role in decisions related to their continuation to higher education and the selection of stream of study/education. These characteristics comprise of parental education, social/caste/ethnic group, religious affiliation, family size, sibling composition, financial status of the family etc. Several studies in international literature have investigated statistical associations between students' subject choices (especially towards Science, Mathematics, technical or vocational courses) and socio-demographic factors likely to influence those choices. Some of these studies focused exclusively on subject choices relating to the final two years of compulsory education [52] [53] and some investigated post-16 students [39] [45] [54]-[56]. A few studies also explored gender differences in young people's reasons for their post-16 subject choices in relation to the study of mathematics and/or science subjects [39]-[45]. Cultural models often entail ideological values that serve to construct social groups and social identities, such as those defined by aspects of gender, ethnicity and class [57]. Arguably students' positions are maintained through various ideologies, which are understood to be sets of factual and evaluative beliefs (socially shared belief systems) which people acquire through the accumulated experience and draw upon to help make sense of the world, and to engage in patterned social practices [58]. A number of studies have found significant impact of the social environment [59], financial characteristics [60] [61] and net cost in education [62] while examining the individuals' 
college-choice decisions.

The factors such as peer influence, parent's choice, teachers' advice, family prestige/public image etc. often govern the psychological mindset of the individual towards opting for a particular field of study at higher education level. Several studies have concluded that family, peers, and agents have an impact on education choice and affect the persistence of students in the education system [63]-[65]. A Lipman Hearne report (2009) claimed parents are deeply involved and influential to their high-achieving children's college choices [66] [67]. The report also found open houses, dialogue with college friends, alumni, and admitted-student programs are extremely influential to students. The report claimed these sources are not well known, but very powerful to student's decision making for their college. The study also found $26 \%$ of sampled students paid a specialist or advisor during the college decision process.

Moreover, there are several institutional, infrastructural and developmental factors which directly or indirectly determine the course of study opted by an individual. These contextual factors may include the type of educational institution, medium of instruction, government sponsorship/subsidies in terms of fee waiving and by providing scholarships or stationary support, accessibility to educational institution, quality of education/teaching material, job-market demand, advertisement/marketing of college/courses, competition for limited seats in higher educational institute, and the overall development of the region/community etc. James et al. (1999) has identified a range of factors influencing course preference including: the reputation of the course among employers; graduate satisfaction from the course; graduate employment rates from the course; the quality of teaching in the course; approaches to teaching, learning and assessment from the course including opportunities for flexible study [18]. Studies have well recognized the significance of the institutional climate [16], and institutional characteristics [15] [51] in a comprehensive college choice model. Geography also imposes constraints on college choices. That most students attend public, in-state institutions implies that college options are circumscribed by state of residence [68]. The impact of geographical regions [55] and urbanity [54] on students' choice of mathematics and science subjects have also been examined empirically.

\section{Methods}

\subsection{Data}

This study is based on the information collected by the $64^{\text {th }}$ round of National Sample Survey (NSS) on "Participation and Expenditure in Education" (Schedule 25.2) in India during July 2007-June 2008. With a nationally representative sample of 445,960 persons from 63,318 rural and 37,263 urban households spread over the country, the survey adopted a stratified multi-stage sampling design. The NSS is a standard and impeccable source of information on a range of socioeconomic issues in India, which is conducted by the National Sample Survey Office (NSSO) of the National Statistical Organisation under the aegis of the Ministry of Statistics and Programme Implementation, Government of India. The major purpose of the schedule 25.2 was to canvass on a range of information related to education including educational infrastructure, current attendance status, educational incentives, magnitude and nature of private expenditure, and the extent of educational wastage in terms of dropout and discontinuance, and its causes. The survey covered the entire Indian Union except Leh (Ladakh) and Kargil districts of Jammu \& Kashmir (for central sample), interior villages of Nagaland situated beyond five kilometers of the bus route and villages in Andaman and Nicobar Islands, which remain inaccessible throughout the year. To make the estimates representative and comparable, and to account for the multi-stage sampling design adopted in the survey, we used appropriate weights in the analysis recommended by the NSS. The details of the sampling weights as well as the extensive information on survey design, data collection, and management procedures are described in the $64^{\text {th }}$ round NSS report [69] and supplementary documents provided with the electronic data disk.

\subsection{Limitations of Data}

In order to comprehensively analyze the factors of subject-choice by individual at post-secondary level education, we required to accommodate all possible dimensions of potential determinants, as conceived in Figure 1. However, this study could not manage to arrange information on some of the indicators such as related to psychosocial factors; a few individual indicators like personal ambition, previous academic performance etc.; as well as a range of contextual variables such as teacher-student interaction, availability of quality teaching material, 
job market demand, advertisement/marketing of courses, and extent of competition etc. In fact, the application of such a comprehensive model is seldom empirically examined. Despite these limitations, analysis of a range of potential factors included in this study representing a national-level scenario is among the rare efforts ever made in Indian context while analyzing the determinants of subject-choice decisions at higher-level education. Acknowledging these limitations, the analysis and findings of this study are expected to augment further inquiries in this field of study.

\subsection{Measures Used in the Study}

The extensive information on educational status and associated features were collected for household members aged 5 - 29 years who were currently (at the time of the survey) attending at primary level education and above. The mutually exclusive academic course selection ${ }^{1}$ by an individual at post-secondary level was used as the outcome variable in the study. Selecting an optional course of study is a general practice in Indian education system after the secondary level education. More often, the selection of study courses at post-secondary level leads to the continuation of higher education in India with a few exceptions. The outcome variable is categorized in four major groups of courses, i.e. Arts/Humanities, Science, Commerce, and Technical/Professional/Vocational. The first three categories are considered under general education, whereas the fourth category involves the hands on training in addition to theoretical classes. Education, such as Engineering, Medicine, Agriculture, Management, Chartered Accountancy, Cost Accountancy etc. are examples of technical/professional courses. The education which aims at imparting training in very specific fields through providing significant "hands on" experience in acquiring necessary skill, which make them employable or create for them opportunities of self employment and the degree/diploma/certificate awarded by the institute should have recognition by State/Central Government/public sector or similar employers are included under vocational education [69]. The education offered by Industrial Training Institutes (ITI), polytechnics, etc. are examples of vocational courses.

The likelihood of selection of these academic courses at the senior secondary and higher education level was assessed using a set of selected socioeconomic, regional and institutional factors. The individual and household factors such as sex/gender (male/female), age at entry in school ( $\leq 5$ years $/ \geq 6$ years), parents' education level (not literate/below primary/primary/middle/secondary \& higher), social group (scheduled tribes (ST)/scheduled castes (SC)/Others), religion (Hindu/Islam/Christian/Others), household size ( $\leq 5 / 6-9 / \geq 10)$, sibling composition, and household economic status were selected from the available information in the survey data. The categorization of exposure variables was based on the discretion in order to account adequate sample size to offer robust estimates from the multivariate analysis. However, the categorization approach followed the general practices applied in policy and programme execution. For instance, based on the terminology adopted by the Government of India, the social group was classified in three categories, which focuses more on the socially disadvantaged castes/groups, and all privileged caste groups are represented in the "Others" group [70]. Siblings of the individual were segregated by sex, and classified based on their numbers in the household. The categories for sibling composition includes: only son in the household, only daughter, 1 brother and 1 sister, more than one $(1+)$ brothers and no sister, more than one brothers and one sister, more than one brothers and sisters, and other mixed composition. The quintile of the monthly per capita household expenditure (MPCE) was adopted as a surrogate variable representing the household economic status of the individual. In the absence of direct data on income in household sample surveys such as NSS, the household expenditure is widely used as a surrogate indicator for assessing the economic status of the households [71] [72].

Institutional factors include type of educational institution (Government or Public/Private), medium of instruction in the course for which a student is enrolled (English/Hindi/Other language), status of free education (free/partially exempted from the tuition fee/neither free nor exempted), scholarship received for opting particular course (yes/no), books or stationary received for free or at subsidized rate (yes/no), distance of educational institution from the place of residence $(1-2 \mathrm{~km} />2 \mathrm{~km}$ ), and mode of transport up to the institution (on foot/ school or public vehicle with no concession/public vehicle with concession/bicycle or other modes). The type of residence (rural/urban) and the region of residence (broad geographical regions) were two regional factors included in the multivariate analysis. The census of India definition of urban/rural is used to classify a household

\footnotetext{
${ }^{1}$ The use of the term "subject-selection" or "subject-choice" throughout the paper should not be assumed to indicate that all students were completely free to choose whatever subjects they liked. Even at post-16 level, choice may be constrained in many ways; students may only be superficially free to choose, or not free to choose at all.
} 
as urban or not [73]. The broad geographical regions were formed based on homogeneity and contiguity of states in different parts of the country [74], which also carry diverse development records.

\subsection{Statistical Analysis}

The proportions were estimated with 95\% confidence intervals (CI) using appropriate sampling weights and accounting for survey design [75]. The bivariate association between the outcome variable and the independent predictors were assessed using chi-squared tests [76]. Moreover, since the nature of the outcome variable was nominal and classified into four categories (i.e. polytomous), the analysis used the multinomial logistic regression model [77]. However, to avoid any complexity in the interpretation and for easier dissemination of the results obtained from the regression model, we report the model-based predicted probabilities (PP) with 95\% CI. These predicted probabilities can be converted to percentage form and are easily interpreted. The general formulation of the model in probabilistic form may be specified as [78] [79];

$$
P_{j}=\frac{e^{\sum_{k} b_{j k} X_{k}}}{1+\sum_{i} e^{\sum_{k} b_{j k} X_{k}}}, j=1,2, \cdots, J
$$

where $P_{j}$ denotes the response variable with $J$ mutually exclusive and exhaustive categories, denoting $j=1,2, \cdots$, $J$ (i.e. 4). The three probability categories of the response variable are: $P_{1}=$ estimated probability for selecting Arts/Humanities courses, $\mathrm{P}_{2}=$ estimated probability for selecting Science, $P_{3}=$ estimated probability for selecting Commerce, and $P_{4}=$ estimated probability for selecting Technical/Profession/Vocational courses. $X_{0}=1$, the summation $\Sigma_{k}$ ranges from $k=0$ to $k=K$, the summation $\Sigma_{i}$ ranges from $i=1$ to $i=J-1$, and $b_{j 0}, b_{j 1}, \cdots$, $b_{j K}$ are all defined to be zero. The latter definition implies that $e^{\sum_{k} b_{j k} X_{k}}=e^{0}=1$, when $j=J$.

Since the study considered a range of covariates in the model, we examined for multicollinearity with variance inflation factors, all of which were much lower than 2.5, suggesting that the possibility of high multicollinearity was ostensible. The final analytic sample size by each predictor variable used in the multivariate model is reported in Table A1. All analyses were conducted using STATA version 10 [80].

\section{Results}

\subsection{Proportion of Population with Post-Secondary Level Education}

Table 1 presents the prevalence (\%) of population aged 15 years and above with senior secondary and higher level education in India by their background characteristics during 2007-08. With nearly $14 \%$ population aged $\geq$ 15 years achieving post-secondary level education, the country demonstrated a wide variation in the proportion across different socioeconomic, demographic and regional groups. Female, rural, and population belonging to SC/ST and Muslim households were disadvantaged in achieving post-secondary level education, as these groups of population were nearly half in proportion compared to male, urban, non-SC/ST (others), and Hindu (and other religious group) population respectively. The economic status manifested a linear pattern, as the proportion increased with the increasing level of monthly per capita expenditure. However, the age group and the household size had non-linear pattern, where the highest proportion of population with post-secondary education was estimated in the age group 20 - 24 years and in households with five members or less. Island and Union Territories (excluding Delhi) recorded the highest proportion of population with post-secondary level education. Western, northern and southern regions of the country recorded less variation in proportion and were above national average. The lowest proportion of population with post-secondary education was recorded in the eastern region of India, whereas the central region recorded slightly lower proportion than the national average.

\subsection{Predictors of Course-Selection in Post-Secondary Education}

Given the low participation rate in post-secondary education in India, there are indications of a skewed pattern in the selection of academic courses as well. More than half of the total population aged $\leq 29$ years, who were attending any educational institution at the time of survey, were likely to opt for Arts/Humanities courses adjusting for selected socioeconomic, regional and institutional factors at their mean (Figure 2). Approximately one in every five students aged $\leq 29$ years had chance to opt for Science courses, whereas nearly $13 \%$ and $12 \%$ students were likely to choose Commerce and Technical/Professional/Vocational (TPV) courses respectively. 
C. Kumar et al.

Table 1. Proportion of population (aged $\geq 15$ years) with senior secondary and higher level education by their background characteristics, India, 2007-08.

\begin{tabular}{|c|c|c|}
\hline Background Characteristics & Proportion (\%) & $95 \% \mathrm{CI}$ \\
\hline \multicolumn{3}{|l|}{ Sex } \\
\hline Male & 17.0 & $(16.5,17.4)$ \\
\hline Female & 9.6 & $(9.6,10.3)$ \\
\hline \multicolumn{3}{|l|}{ Age group } \\
\hline $15-19$ & 9.2 & $(8.8,9.6)$ \\
\hline $20-24$ & 24.6 & $(23.6,25.5)$ \\
\hline $25-29$ & 18.8 & $(18.1,19.6)$ \\
\hline $30-34$ & 15.5 & $(14.9,16.1)$ \\
\hline $35-39$ & 13.7 & $(13.1,14.3)$ \\
\hline$\geq 40$ & 9.3 & $(8.9,9.7)$ \\
\hline \multicolumn{3}{|l|}{ Social group } \\
\hline ST & 5.1 & $(4.7,5.5)$ \\
\hline SC & 7.4 & $(7.1,7.8)$ \\
\hline Others & 16.1 & $(15.6,16.6)$ \\
\hline \multicolumn{3}{|l|}{ Religion } \\
\hline Hindu & 14.0 & $(13.6,14.4)$ \\
\hline Islam & 7.7 & $(7.1,8.3)$ \\
\hline Christian & 20.6 & $(18.8,22.5)$ \\
\hline Others & 17.3 & $(15.7,18.9)$ \\
\hline \multicolumn{3}{|l|}{ Household size } \\
\hline$\leq 5$ & 15.2 & $(14.8,15.7)$ \\
\hline $6-9$ & 10.8 & $(10.4,11.2)$ \\
\hline$\geq 10$ & 12.0 & $(11.1,12.9)$ \\
\hline \multicolumn{3}{|l|}{$M P C E^{\mathrm{a}}$ quintile } \\
\hline Q1 & 3.4 & $(3.1,3.7)$ \\
\hline Q2 & 5.4 & $(5.1,5.7)$ \\
\hline Q3 & 8.4 & $(8.0,8.8)$ \\
\hline Q4 & 14.1 & $(13.6,14.7)$ \\
\hline Q5 & 38.0 & $(36.9,39.2)$ \\
\hline \multicolumn{3}{|l|}{ Type of residence } \\
\hline Rural & 8.0 & $(7.7,8.3)$ \\
\hline Urban & 27.7 & $(26.8,28.6)$ \\
\hline \multicolumn{3}{|l|}{ Region of residence } \\
\hline North & 15.7 & $(14.8,16.7)$ \\
\hline Central & 12.5 & $(11.7,13.3)$ \\
\hline
\end{tabular}




\section{Continued}

$\begin{array}{ccc}\text { East } & 9.5 & (8.9,10.1) \\ \text { West } & 16.6 & (15.7,17.7) \\ \text { South } & 15.0 & (14.1,15.9) \\ \text { Northeast } & 10.7 & (9.6,12.0) \\ \text { Island/UTs } & 27.9 & (23.5,32.8) \\ \text { Total } & \mathbf{1 3 . 5} & \mathbf{( 1 3 . 2 , 1 3 . 9 )}\end{array}$

${ }^{\mathrm{a}}$ Monthly Per Capita Expenditure

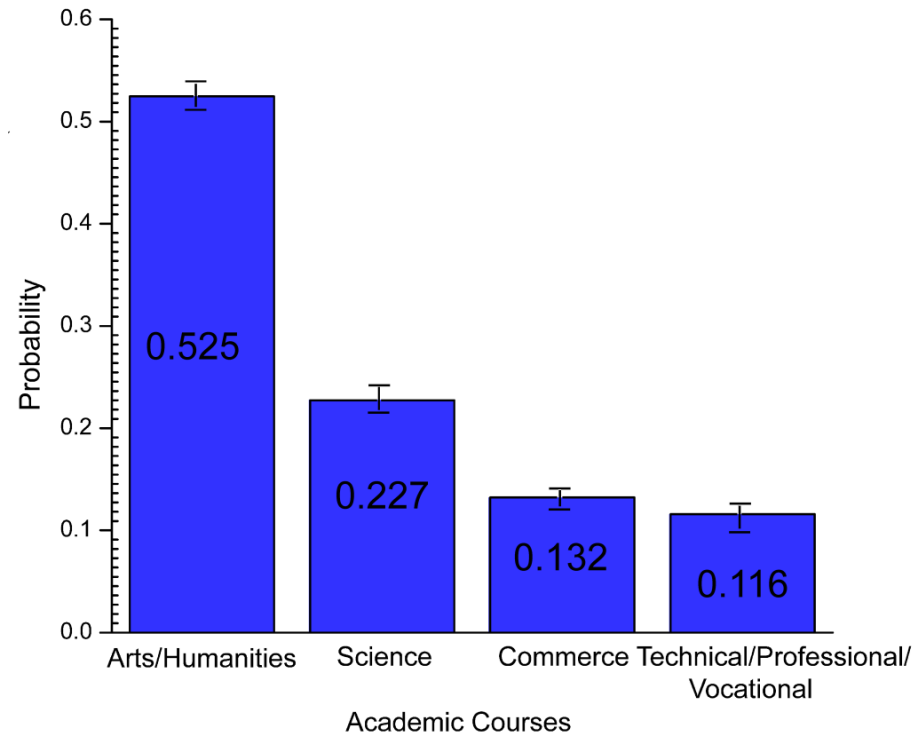

Figure 2. Overall probability (with 95\% CI) to select academic courses in post-secondary level education (currently attending population aged $\leq 29$ ) adjusting for selected socioeconomic, regional and institutional factors at their mean, India, 2007-08.

Table 2 presents the predicted probabilities of population aged $\leq 29$ years for opting four major categories of group of academic courses in post-secondary level education controlling for all selected variables (listed in the table) in the multinomial logit model. Among individual/household factors, sex/gender, age at entry in school, father's and mother's education level, religion, household size, and economic status were found statistically significant predictors of course selection. Female students were observed more likely to opt for Arts/Humanities courses compared to their male counterparts, while their participation in Science, Commerce, and TPV courses were relatively lower than the male students. Students who entered early (at age $\leq 5$ years) in school were more likely to go for Science and Commerce courses, while there was little impact of age at entry in school on selection of TPV courses. Although, the education level of father's and mother's separately had no linear and static pattern on individual's choice of particular academic course, however, more than a quarter of the sample population were likely to opt for Science courses in post-secondary education, whose father's and mother's education level were secondary and higher. Hindu population was observed relatively more likely to select Science and TPV courses compared to other religious groups. Household size had a distinct pattern on course selection. Sample population from small size ( $\leq 5$ members) households were relatively more likely to choose Science courses, while population from medium size (6 - 9 members) and large size ( $\geq 10$ members) households were observed opting for Commerce and TPV courses more than other groups respectively. Except for Commerce courses and to some extent TPV courses, the economic status of household did not appear to have a linear and static pattern in particular course selection at post-secondary level. 
Table 2. Predicted probabilities (PP) with 95\% confidence intervals (CI) for opting courses at senior secondary and higher education level across categories of selected socioeconomic, regional and institutional determinants, India, 2007-08.

\begin{tabular}{|c|c|c|c|c|c|c|c|c|c|}
\hline \multirow{2}{*}{ Selected covariates } & \multicolumn{2}{|c|}{ Arts/Humanities } & \multicolumn{2}{|r|}{ Science } & \multicolumn{2}{|c|}{ Commerce } & \multicolumn{2}{|c|}{$\begin{array}{c}\text { Technical/Professional/ } \\
\text { Vocational }\end{array}$} & \multirow{2}{*}{$p$-value } \\
\hline & $\mathrm{PP}$ & $95 \%$ CI & $\mathrm{PP}$ & $95 \%$ CI & PP & $95 \%$ CI & $\mathrm{PP}$ & $95 \%$ CI & \\
\hline $\operatorname{Sex}$ & & & & & & & & & $<0.001$ \\
\hline Male & 0.476 & $(0.453,0.499)$ & 0.254 & $(0.235,0.273)$ & 0.142 & $(0.127,0.157)$ & 0.128 & $(0.114,0.142)$ & \\
\hline Female & 0.593 & $(0.567,0.619)$ & 0.191 & $(0.171,0.210)$ & 0.117 & $(0.101,0.133)$ & 0.099 & $(0.084,0.114)$ & \\
\hline Age at entry in school & & & & & & & & & $<0.001$ \\
\hline$\leq 5$ & 0.503 & $(0.484,0.522)$ & 0.241 & $(0.225,0.256)$ & 0.145 & $(0.132,0.158)$ & 0.111 & $(0.099,0.123)$ & \\
\hline$\geq 6$ & 0.567 & $(0.541,0.599)$ & 0.200 & $(0.180,0.221)$ & 0.108 & $(0.093,0.123)$ & 0.125 & $(0.108,0.142)$ & \\
\hline Father's education level & & & & & & & & & $<0.001$ \\
\hline Not literate & 0.561 & $(0.515,0.607)$ & 0.188 & $(0.153,0.222)$ & 0.144 & $(0.112,0.176)$ & 0.107 & $(0.079,0.135)$ & \\
\hline Below Primary & 0.505 & $(0.451,0.560)$ & 0.222 & $(0.180,0.265)$ & 0.145 & $(0.108,0.182)$ & 0.127 & $(0.092,0.163)$ & \\
\hline Primary & 0.573 & $(0.529,0.617)$ & 0.225 & $(0.190,0.259)$ & 0.108 & $(0.084,0.133)$ & 0.094 & $(0.073,0.115)$ & \\
\hline Middle & 0.556 & $(0.522,0.589)$ & 0.189 & $(0.164,0.215)$ & 0.150 & $(0.127,0.173)$ & 0.105 & $(0.086,0.124)$ & \\
\hline Secondary \& Higher & 0.489 & $(0.464,0.515)$ & 0.257 & $(0.236,0.279)$ & 0.126 & $(0.110,0.141)$ & 0.127 & $(0.111,0.143)$ & \\
\hline Mother's education level & & & & & & & & & 0.003 \\
\hline Not literate & 0.562 & $(0.533,0.592)$ & 0.229 & $(0.204,0.254)$ & 0.102 & $(0.085,0.119)$ & 0.107 & $(0.089,0.124)$ & \\
\hline Below Primary & 0.519 & $(0.464,0.573)$ & 0.196 & $(0.156,0.235)$ & 0.153 & $(0.117,0.188)$ & 0.133 & $(0.101,0.165)$ & \\
\hline Primary & 0.520 & $(0.484,0.555)$ & 0.222 & $(0.193,0.251)$ & 0.148 & $(0.123,0.173)$ & 0.110 & $(0.089,0.131)$ & \\
\hline Middle & 0.532 & $(0.493,0.570)$ & 0.202 & $(0.175,0.229)$ & 0.144 & $(0.120,0.168)$ & 0.123 & $(0.101,0.145)$ & \\
\hline Secondary \& Higher & 0.474 & $(0.438,0.510)$ & 0.256 & $(0.227,0.285)$ & 0.150 & $(0.126,0.174)$ & 0.120 & $(0.101,0.139)$ & \\
\hline Social group & & & & & & & & & 0.162 \\
\hline ST & 0.610 & $(0.539,0.681)$ & 0.178 & $(0.120,0.236)$ & 0.114 & $(0.072,0.156)$ & 0.098 & $(0.055,0.141)$ & \\
\hline SC & 0.525 & $(0.486,0.565)$ & 0.212 & $(0.180,0.244)$ & 0.128 & $(0.102,0.154)$ & 0.135 & $(0.109,0.160)$ & \\
\hline Others & 0.520 & $(0.502,0.537)$ & 0.233 & $(0.219,0.247)$ & 0.134 & $(0.122,0.145)$ & 0.113 & $(0.102,0.125)$ & \\
\hline Religion & & & & & & & & & 0.027 \\
\hline Hindu & 0.514 & $(0.497,0.531)$ & 0.233 & $(0.219,0.246)$ & 0.132 & $(0.121,0.143)$ & 0.121 & $(0.110,0.133)$ & \\
\hline Islam & 0.567 & $(0.515,0.619)$ & 0.220 & $(0.182,0.258)$ & 0.132 & $(0.102,0.161)$ & 0.081 & $(0.059,0.103)$ & \\
\hline Christian & 0.592 & $(0.503,0.682)$ & 0.174 & $(0.119,0.230)$ & 0.138 & $(0.088,0.189)$ & 0.095 & $(0.059,0.131)$ & \\
\hline Others & 0.587 & $(0.516,0.658)$ & 0.165 & $(0.111,0.219)$ & 0.134 & $(0.089,0.180)$ & 0.114 & $(0.077,0.151)$ & \\
\hline Household size & & & & & & & & & 0.001 \\
\hline$\leq 5$ & 0.521 & $(0.499,0.543)$ & 0.234 & $(0.216,0.251)$ & 0.124 & $(0.110,0.138)$ & 0.121 & $(0.107,0.135)$ & \\
\hline $6-9$ & 0.523 & $(0.493,0.554)$ & 0.226 & $(0.202,0.250)$ & 0.152 & $(0.131,0.173)$ & 0.099 & $(0.083,0.114)$ & \\
\hline$\geq 10$ & 0.552 & $(0.477,0.628)$ & 0.155 & $(0.106,0.204)$ & 0.116 & $(0.067,0.165)$ & 0.176 & $(0.118,0.233)$ & \\
\hline Sibling composition & & & & & & & & & 0.281 \\
\hline Only Son & 0.479 & $(0.417,0.542)$ & 0.280 & $(0.230,0.330)$ & 0.113 & $(0.083,0.143)$ & 0.127 & $(0.095,0.160)$ & \\
\hline
\end{tabular}




\section{Continued}

\begin{tabular}{|c|c|c|c|c|c|c|c|c|c|}
\hline Only daughter & 0.529 & $(0.449,0.609)$ & 0.238 & $(0.179,0.297)$ & 0.102 & $(0.057,0.148)$ & 0.131 & $(0.090,0.173)$ & \\
\hline 1 brother, 1 sister & 0.506 & $(0.467,0.544)$ & 0.221 & $(0.193,0.249)$ & 0.156 & $(0.129,0.182)$ & 0.118 & $(0.097,0.139)$ & \\
\hline $1+$ brother, no sister & 0.510 & $(0.470,0.550)$ & 0.243 & $(0.210,0.275)$ & 0.137 & $(0.113,0.161)$ & 0.111 & $(0.089,0.132)$ & \\
\hline $1+$ brother, 1 sister & 0.545 & $(0.509,0.580)$ & 0.217 & $(0.190,0.244)$ & 0.138 & $(0.114,0.161)$ & 0.101 & $(0.082,0.119)$ & \\
\hline $1+$ brother, $1+$ sister & 0.542 & $(0.493,0.590)$ & 0.204 & $(0.166,0.242)$ & 0.130 & $(0.099,0.162)$ & 0.124 & $(0.094,0.155)$ & \\
\hline Other mixed composition & 0.533 & $(0.497,0.568)$ & 0.226 & $(0.198,0.254)$ & 0.120 & $(0.099,0.140)$ & 0.122 & $(0.100,0.143)$ & \\
\hline$M P C E^{\mathrm{b}}$ quintile & & & & & & & & & 0.007 \\
\hline Q1 & 0.553 & $(0.491,0.616)$ & 0.238 & $(0.184,0.293)$ & 0.096 & $(0.058,0.134)$ & 0.112 & $(0.073,0.151)$ & \\
\hline Q2 & 0.577 & $(0.532,0.621)$ & 0.224 & $(0.187,0.262)$ & 0.102 & $(0.076,0.129)$ & 0.097 & $(0.072,0.123)$ & \\
\hline Q3 & 0.554 & $(0.520,0.588)$ & 0.233 & $(0.204,0.262)$ & 0.114 & $(0.095,0.134)$ & 0.099 & $(0.081,0.118)$ & \\
\hline Q4 & 0.536 & $(0.505,0.567)$ & 0.218 & $(0.194,0.243)$ & 0.137 & $(0.116,0.157)$ & 0.109 & $(0.092,0.126)$ & \\
\hline Q5 & 0.482 & $(0.454,0.510)$ & 0.226 & $(0.205,0.248)$ & 0.156 & $(0.137,0.176)$ & 0.136 & $(0.117,0.154)$ & \\
\hline Type of institution & & & & & & & & & $<0.001$ \\
\hline Govt./Public & 0.564 & $(0.543,0.585)$ & 0.197 & $(0.181,0.213)$ & 0.134 & $(0.120,0.148)$ & 0.105 & $(0.092,0.118)$ & \\
\hline Private & 0.479 & $(0.456,0.502)$ & 0.264 & $(0.244,0.283)$ & 0.129 & $(0.115,0.144)$ & 0.128 & $(0.113,0.143)$ & \\
\hline Medium of instruction & & & & & & & & & $<0.001$ \\
\hline English & 0.304 & $(0.278,0.330)$ & 0.333 & $(0.305,0.362)$ & 0.144 & $(0.125,0.164)$ & 0.219 & $(0.194,0.244)$ & \\
\hline Hindi & 0.647 & $(0.613,0.681)$ & 0.167 & $(0.142,0.192)$ & 0.096 & $(0.075,0.117)$ & 0.090 & $(0.073,0.108)$ & \\
\hline Others & 0.622 & $(0.594,0.651)$ & 0.174 & $(0.153,0.195)$ & 0.140 & $(0.119,0.160)$ & 0.064 & $(0.052,0.076)$ & \\
\hline Status of free education & & & & & & & & & $<0.001$ \\
\hline Free & 0.547 & $(0.515,0.578)$ & 0.293 & $(0.265,0.322)$ & 0.118 & $(0.099,0.136)$ & 0.042 & $(0.031,0.053)$ & \\
\hline Partially exempted & 0.501 & $(0.401,0.600)$ & 0.200 & $(0.130,0.271)$ & 0.082 & $(0.036,0.129)$ & 0.216 & $(0.148,0.285)$ & \\
\hline Neither free nor exempted & 0.505 & $(0.486,0.523)$ & 0.204 & $(0.190,0.218)$ & 0.136 & $(0.124,0.148)$ & 0.156 & $(0.142,0.169)$ & \\
\hline Scholarship received & & & & & & & & & 0.906 \\
\hline Yes & 0.535 & $(0.490,0.581)$ & 0.230 & $(0.191,0.269)$ & 0.125 & $(0.097,0.154)$ & 0.109 & $(0.080,0.138)$ & \\
\hline No & 0.523 & $(0.507,0.540)$ & 0.227 & $(0.213,0.240)$ & 0.133 & $(0.122,0.144)$ & 0.117 & $(0.106,0.128)$ & \\
\hline Books/stationery received ${ }^{\mathrm{a}}$ & & & & & & & & & 0.841 \\
\hline Yes & 0.488 & $(0.379,0.596)$ & 0.257 & $(0.164,0.349)$ & 0.151 & $(0.076,0.226)$ & 0.105 & $(0.035,0.174)$ & \\
\hline No & 0.525 & $(0.509,0.541)$ & 0.227 & $(0.214,0.240)$ & 0.132 & $(0.121,0.143)$ & 0.116 & $(0.105,0.127)$ & \\
\hline Distance of institution & & & & & & & & & $<0.001$ \\
\hline $1-2 \mathrm{~km}$ & 0.511 & $(0.476,0.547)$ & 0.283 & $(0.252,0.313)$ & 0.121 & $(0.101,0.141)$ & 0.085 & $(0.068,0.102)$ & \\
\hline$>2 \mathrm{~km}$ & 0.527 & $(0.506,0.548)$ & 0.206 & $(0.190,0.221)$ & 0.136 & $(0.122,0.151)$ & 0.131 & $(0.118,0.145)$ & \\
\hline
\end{tabular}




\section{Continued}

\begin{tabular}{|c|c|c|c|c|c|c|c|c|c|}
\hline Mode of transport & & & & & & & & & $<0.001$ \\
\hline On foot & 0.591 & $(0.553,0.628)$ & 0.225 & $(0.195,0.255)$ & 0.119 & $(0.096,0.142)$ & 0.065 & $(0.050,0.080)$ & \\
\hline $\begin{array}{l}\text { School/Public Vehicle } \\
\text { with no concession }\end{array}$ & 0.475 & $(0.438,0.511)$ & 0.207 & $(0.179,0.235)$ & 0.123 & $(0.101,0.146)$ & 0.195 & $(0.168,0.223)$ & \\
\hline $\begin{array}{l}\text { Public Vehicle } \\
\text { with concession }\end{array}$ & 0.507 & $(0.472,0.542)$ & 0.207 & $(0.182,0.232)$ & 0.151 & $(0.129,0.173)$ & 0.135 & $(0.114,0.157)$ & \\
\hline Bicycle/Others & 0.503 & $(0.475,0.531)$ & 0.250 & $(0.228,0.272)$ & 0.130 & $(0.113,0.148)$ & 0.116 & $(0.100,0.132)$ & \\
\hline Type of residence & & & & & & & & & $<0.001$ \\
\hline Rural & 0.580 & $(0.558,0.602)$ & 0.211 & $(0.194,0.228)$ & 0.096 & $(0.084,0.107)$ & 0.113 & $(0.099,0.127)$ & \\
\hline Urban & 0.446 & $(0.421,0.472)$ & 0.242 & $(0.222,0.263)$ & 0.195 & $(0.175,0.215)$ & 0.116 & $(0.101,0.132)$ & \\
\hline Region of residence & & & & & & & & & $<0.001$ \\
\hline North & 0.644 & $(0.606,0.681)$ & 0.143 & $(0.120,0.167)$ & 0.101 & $(0.078,0.125)$ & 0.112 & $(0.091,0.132)$ & \\
\hline Central & 0.487 & $(0.442,0.533)$ & 0.293 & $(0.252,0.335)$ & 0.123 & $(0.094,0.152)$ & 0.096 & $(0.073,0.119)$ & \\
\hline East & 0.706 & $(0.671,0.740)$ & 0.171 & $(0.142,0.200)$ & 0.058 & $(0.043,0.073)$ & 0.065 & $(0.049,0.081)$ & \\
\hline West & 0.488 & $(0.451,0.526)$ & 0.149 & $(0.125,0.173)$ & 0.211 & $(0.181,0.241)$ & 0.152 & $(0.127,0.177)$ & \\
\hline South & 0.368 & $(0.333,0.404)$ & 0.330 & $(0.297,0.362)$ & 0.167 & $(0.142,0.192)$ & 0.135 & $(0.114,0.156)$ & \\
\hline Northeast & 0.809 & $(0.761,0.858)$ & 0.090 & $(0.049,0.130)$ & 0.038 & $(0.017,0.058)$ & 0.063 & $(0.033,0.093)$ & \\
\hline Island/UTs & 0.543 & $(0.444,0.642)$ & 0.213 & $(0.143,0.283)$ & 0.110 & $(0.062,0.157)$ & 0.134 & $(0.083,0.185)$ & \\
\hline
\end{tabular}

${ }^{\mathrm{a}}$ For free or at subsidized rate; ${ }^{\mathrm{b}}$ Monthly Per Capita Expenditure; $p$-value refers to adjusted Wald test. Note: Predicted probabilities are based on the multivariate multinomial logistic regression model and adjusted for all covariates at their mean.

Among selected institutional factors, type of educational institution, medium of academic instruction, the status of free education, distance of educational institution from the place of residence, and mode of transport were observed statistically significant predictors for academic course selection. Population attending private educational institutions was found more likely to opt for Science and TPV courses. Similarly, the medium of instruction in educational institutions had a profound impact on selection of Science and TPV courses. More than 33\% of sample population who availed their academic instruction in English were likely to opt for Science courses compared to nearly $17 \%$ population for each who got instruction in Hindi and other languages. Population who got free education and whose tuition fee was partially exempted appeared more likely to choose Science courses and TPV courses respectively. Nearly 28\% sample population whose institution happened to be within $2 \mathrm{~km}$ from their residences, appeared to opt for Science courses compared to $21 \%$ population who used to stay beyond $2 \mathrm{~km}$ from their educational institutions. However, the pattern was observed opposite in the selection of other academic courses. As it is apparent in Table 2, although, the population whose institution were beyond $2 \mathrm{~km}$ from their residences had higher probability to select Commerce and TPV courses, these courses were also relatively more likely to be opted by population used to travel by public vehicle with transport concession.

The urban population was found more advantageous compared to their rural counterparts in pursuing Science, Commerce and TPV courses in post-secondary education. Population belonging to the southern and the central regions of India had higher probabilities to pursue Science courses, while the population from the western region recorded the highest probability to opt for Commerce and TPV courses in post-secondary level education compared to population from other regions.

\section{Discussion}

As given the apparent socioeconomic differences in the attainment of post-secondary education, the differences in selection of academic courses did not appear clearly distinct and following any specific pattern. This suggests 
that subject choice at the higher level is an interweaving function of a number of socioeconomic, psychosocial, political, regional and institutional factors, yet there are chances some of the evident patterns may remain unanswered. This study, however, obtained that sex/gender, age at entry in school, father's and mother's education level, religion, household size, and economic status were statistically significant predictors of course selection among individual/household factors. Besides, the selection of courses was also significantly different by the institutional factors such as type of educational institution, medium of academic instruction, the status of free education, distance of educational institution from the place of residence, and mode of transport along with the pertinent influence of type and region of residence.

Although a few studies investigated the role of gender in subject choices at the higher level, this still adds strength to the conclusion that male and female students make different subject choices that are not explained by systematic differences in ability, socioeconomic, ethnic, or institutions' organisational factors [81]-[83]. The issues that were most commonly raised as important influences on whether or not STEM (Science, Technology, Engineering and Mathematics) subjects were pursued at the higher level were the utility of the subject for future education or career purposes, enjoyment or interest in the subject, perceived ability in the subject, subject difficulty, and the importance of taking subjects that complemented one another [81] [84]. There is some evidence that girls are more likely than boys to give interest and enjoyment as a reason for their choice of certain STEM subjects, and some evidence that boys are more likely than girls to say that the easiness of the subject influenced them. Students' perceptions about their ability and subject difficulty also illuminate the link between prior attainment and subject choice. Given the link between socioeconomic status, school type and attainment [85] and the claimed differences in the way that science is taught between schools, it may be that the organisation of the education system is discouraging pupils with appropriate prior attainment and/or ability from more disadvantaged backgrounds from studying STEM subjects at a higher level. Warrington and Younger (2000) point out that mathematics and science subjects are socially constructed as masculine-it is therefore conceivable that STEM studies are conceived as boys' cultures and tend to alienate girls [86]. Moreover, in Indian/South Asian context, the gender preference in each social phenomenon is well recognized [87] [88]. Single-sex educational institutions may also have a profound influence on the gender differences in perceptions, ability and approach towards particular subjects.

Empirical studies carried out in different parts of the world have examined the extent to which children are likely to choose subjects that are associated with their parents' characteristics [89]-[93]. In general, these studies take the line that parents' interests are communicated to children, and the children are therefore likely to choose subjects that correspond to their parents' interests. According to a framework that integrates rational choice perspectives and cultural reproduction theory, children take their parents' social position as a reference for their own choices, and are guided mainly by the amount of economic and cultural capital that is available within the family [90] [92]-[94]. In relation to education, culture is not static, but changes according to socio-historical circumstances [95]. Cao et al. (2006) investigated the perceived parental influence on mathematics learning in Australia and China [96]. McPhan et al. (2008) identified that parents' occupation and education achievements and siblings were the influencing factor on students' decision to study mathematics [97]. Even some studies suggest that pupils considered parental advice to be far more important than teacher advice in influencing their option decisions [98].

However, in present Indian context, this study found that parents' lower education level were not likely to hinder the students' selection of Science or TPV courses substantially different from that of the parents' higher education level; such findings might be attributed to the increasing mass-media exposure, social network, institutional or other unobserved factors. Similarly, students from lower economic status did not appear to be disadvantaged in the selection of TPV courses substantially compared to the students from the highest economic class, and even the former were found more probable to opt for Science courses compared to the latter.

For the selection of subject field, a related hypothesis elaborates that lower social class students may be more inclined to choose subjects that offer better labour market prospects [99]. Moreover, Kelsall et al. (1972) maintain that lower social class students may tend to choose technical fields of study, which are closer to the occupational experience of many manual working class parents [99]. Boudon's (1974) model of "rational action" states that educational choices depend on the perception of the costs and benefits of each educational alternative available [100], which resembles the one commonly used by economists: Becker's (1975) human capital theory. According to Becker (1975) the costs and the returns to education are the main factors driving educational choices [101]. Some fields might be more closely linked to professions for which the presence of "social net- 
works" (to which high social class students are typically better connected) is more important to ensure labour market success and a higher economic return of the educational investment. Moreover, since in the presence of capital market imperfections low social class individuals might have higher costs of enrolling in higher education, standard economic theory predicts that these individuals will require a higher return from their investment in university education [102].

Similar argument may be ascribed while interpreting the higher probability of TPV courses observed among the students from the large size households; however, their probability to opt for science courses was substantially lower compared to the small and medium size households. Moreover, the literature suggests that there is a positive effect of age at school entry on pupils' educational performance [103]-[105]. Given the lower proportion of tertiary education among Muslim (Islam) population, their probability to opt for TPV courses were the lowest among all religious groups, followed by the Christian population. Moreover, Christian and other religious groups had a lower probability to select Science courses. This may suggest the possibility of their engagement in their family businesses or activities, as their probabilities to opt for Commerce courses were relatively higher compared to Hindu and Muslim religious groups.

The role of institutional factors in determining subject choices is obvious, immediate and direct, and the increased impact of these factors in any society is appreciable, because it can be approached later or sooner through effective planning and management of available resources; not as complex as the socio-psychological and behavioural factors to deal with. The selection probability of Science and TPV courses among students in Private institutions and who were instructed in English were higher. The Private institutions are considered better equipped, disciplined, effective compared to the Government/Public institutions, however, the former are far expensive than the latter. Similarly, the higher-level education in Science and TPV courses cannot be pursued without knowing better English, as the standard books and study materials are primarily available in English. Students were likely to prefer Science and TPV courses more if their education expenses were fully waived or partially exempted, which suggests that if the provisions for required economic support to undertake these courses would be made by the Government, the subject orientation can be molded. As at present, the Government provides scholarships and subsidies on books/stationary, as well as transport concessions to continue their higher education, which can be expanded and modified with specific terms and conditions in order to influence students' subject choice as per the need of workforce, however, at early age of education.

The urban advantage in selection of Science and TPV courses are contingent upon the better institutional factors, better-informed social networks and better exposure to labour market and employment trends. Similarly, the deprivation of eastern and northeastern regions in the mainstream development can also have prolific impact on development of educational activities. The number of Government ITIs is very less in eastern region compared to other regions [106] of the country.

\section{Policy Implications}

The combination of subjects/courses one decides to take for higher-level study is the most crucial decision or choice in terms of one's livelihood prospects. As important as these choices are for individuals, such decisions also have wider economic implications for the country. Major government-funded inquiries elsewhere (e.g. [107] [108]) identified a mismatch between skills acquired during formal education and those required in the workplace. This phenomenon is not alien to India. Helping young people to make the most appropriate subject choices is therefore crucial; both to ensure that the country has the skills it needs for the economy and to enable young people to make the best choices to meet their own future needs and aspirations. However, the dynamics of students' subject choice is a significantly under-investigated area in India.

A key premise underpinning many of the proposals is the view that young people begin to make choices about careers early in their education [83]. Schools in India need to make aware of their role in assisting students to make informed choices about future studies and work options during various stages of their educational journey. Such assistance may be indirect, in terms of establishing curriculum structures that allow students to make choices with set alternatives, or direct, in terms of career education or less formal advice given to students to assist them individually in making their subject choices and/or decisions about post school destinations and career choices [109]. Consequently, there should be provision of more funds required for the procurement and installation of machines, and equipment, supply of furniture and fittings, construction of workshop and laboratories and provision of special incentives for vocational teachers in the secondary schools. 
VET (Vocational Education and Training)—in-schools programs are increasing in importance relative to the traditional school to VET pathway [110]. Some studies have investigated the issue of how well the development of vocational learning in schools has helped to keep young people engaged in education [110] [111]. Vocational learning in schools can function as an equity strategy performing a "preventative function" by allowing students "to develop work-related skills while still advancing their general education, and the training encourages young people to stay at school longer [110]. This has potential benefits in both the general education and vocational learning areas [110] and in securing a range of good outcomes for school leavers [111].

In addition, careers guidance in schools is very poor in India. Patton and McCrindle (2001) investigated the role of career information and vocational guidance in students' post-school planning, and reported that students requested more information about their options [112]. Findings suggested that many students would have preferred more assistance when in the year 10 and felt that the year 12 was too late to be making course and career decisions [113].

However, we also need to deal with the sheer inertia of the academic community. Singh (1999) mentions based on his experience that promotion of vocational courses was not well responded by academic community whenever they were asked for [114]. As this mode of education is alien to them, they are reluctant to undertake any new experiment or relearn their academic digits. Nor has there been any shift at the policy-making level. Therefore, a policy of drift has been followed, so much so that students are content to get enrolled in colleges, and study in a casual and half-hearted way and clear their examinations which are not all that rigorous [114]. To some extent, decision-making in our institutions is largely bureaucratic in character; all kinds of misjudgments continue to be made. All these issues need to be given adequate consideration by the policy makers to deal with the barriers faced by the potential population to undertake academic courses as per the market demand.

\section{Conclusion}

This study has empirically examined a range of factors, which were instrumental in determining the course of study at post-secondary level education by individuals (adolescents/youths) in India. Moreover, a comprehensive framework for analyzing the factors of academic-course choice has also been proposed for further research in this field of study. Although, this study could not examine the proposed framework comprehensively due to the lack of required information, nonetheless, the discussions and findings of this study would certainly augment the future research conceptualized with all possible dimensions. The major individual, household and institutional factors were found significant determinants of the choice of subject-course at post-secondary level in India, which can be persuaded to make a balance between the job-market requirements and the trained workforce in order to make plans for the use of available human resource effectively as a bonus. We agree with this fact that supplying human capital to the labour market is not the exclusive role of the higher education, however, jobmarket opportunities are found to significantly affect the subject choice at higher level in several other studies. On the other hand, there are possibilities that adolescents or youths undesirably opt for the subject-courses in their higher education in want of adequate options. Hence, the mismatches between human resource training and workforce engagement could be rectified with certain interventions.

\section{References}

[1] Altbach, P.G., Reisberg, L. and Rumbley, L.E. (2009) Trends in Global Higher Education: Tracking an Academic Revolution. UNESCO 2009 World Conference on Higher Education, Paris, 5-8 July 2009.

[2] NSSO (2008) Employment and Unemployment Situation in India, 2005-06. NSS Report No. 522. National Sample Survey Organisation, Ministry of Statistics and Programme Implementation, Government of India, New Delhi.

[3] Mavi, A.K. (2007) Educated Unemloyed: Problem, Policy, and Measures to Generate Employment. Deep \& Deep Publications Pvt. Ltd., New Delhi.

[4] Dukkipati, U. (2010) Higher Education in India: Sustaining Long-Term Growth? South Asia Monitor (141). Center for Strategic \& International Studies, South Asia Program, Washington DC.

[5] Shahani, S. (2011) Educated but Unemployed, India’s Young Women Suffer Silently. World Pulse, 29 March 2011. http://www.worldpulse.com/node/36221

[6] Srinivasan, R. (2012) Higher Your Education, Harder It Is Getting a Job. The Times of India, 18 July 2012. http://articles.timesofindia.indiatimes.com/2012-07-18/india/32730302_1_unemployment-rate-unemployment-surveyhigher-unemployment 
[7] TOI (The Times of India) (2007) Arts Grads Top List of Educated Unemployed. The Times of India, 11 March 2007. http://articles.timesofindia.indiatimes.com/2007-03-11/india/27875609_1_unemployment-allowance-highest-number-j ob-market

[8] Shukla, R. (2005) India Science Report: Science Education, Human Resources and Public Attitude towards Science and Technology. National Council of Applied Economic Research. http://www.insaindia.org/India\%20Science\%20report-Main.pdf

[9] The Guardian (2012) Graduate Employment: By Skill, Subject and Graduation. The Guardian, 6 March 2012. http://www.guardian.co.uk/news/datablog/2012/mar/06/graduate-employment-low-skill-jobs

[10] Kalmijn, M. and Van der Lippe, T. (1997) Type of Schooling and Sex Differences in Earnings in the Netherlands. European Sociological Review, 13, 1-15. http://dx.doi.org/10.1093/oxfordjournals.esr.a018198

[11] Marini, M.M. and Fan, P.L. (1997) The Gender Gap in Earnings at Career Entry. American Sociological Review, 62, 588-604. http://dx.doi.org/10.2307/2657428

[12] Van de Werfhorst, H.G. and Kraaykamp, G. (2001) Four Field-Related Educational Resources and Their Impact on Labor, Consumption, and Sociopolitical Orientation. Sociology of Education, 74, 296-317. http://dx.doi.org/10.2307/2673137

[13] Nilsson, I. and Ekehammar, B. (1986) Sociopolitical Ideology and Field of Study. Educational Studies, 12, 37-46. http://dx.doi.org/10.1080/0305569860120103

[14] Crotty, W.J. (1967) Democratic Consensual Norms and the College Student. Sociology of Education, 40, 200-218. http://dx.doi.org/10.2307/2112075

[15] Hossler, D., Braxton, J. and Coopersmith, G. (1989) Understanding Student College Choice. Higher Education: Handbook of Theory and Research, 5, 231-288.

[16] Chapman, D.W. (1981) A Model of Student College Choice. Journal of Higher Education, 52, 490-505. http://dx.doi.org/10.2307/1981837

[17] Grace, J.D. (1989) A Personal Decision. Currents, 15, 55-57.

[18] James, R., Baldwin, G. and McInnis, C. (1999) Which University? The Factors Influencing Choices of Prospective Undergraduates, Evaluation and Investigations Programme. Higher Education Division, Australia.

[19] Dixon, P.N. and Martin, N.K. (1991) Measuring Factors that Influence College Choice. NASPA Journal, $29,31-36$.

[20] Martin, N.K. and Dixon, P.N. (1991) Factors Influencing Students' College Choice. Journal of College Student Development, 32, 253-257.

[21] Weiler, W.C. (1994) Transition from Consideration of a College to the Decision to Apply. Research in Higher Education, 35, 631-646. http://dx.doi.org/10.1007/BF02497079

[22] Hearn, J. (1984) The Relative Roles of Academic Ascribed and Socioeconomic Characteristics in College Destinations. Sociology of Education, 57, 22-30. http://dx.doi.org/10.2307/2112465

[23] Jackson, G. (1978) Financial Aid and Student Enrollment. Journal of Higher Education, 49, 548-574. http://dx.doi.org/10.2307/1981139

[24] Tierney, M.L. (1983) Student College Choice Sets: Toward an Empirical Characterization. Research in Higher Education, 18, 271-284. http://dx.doi.org/10.1007/BF00979600

[25] Somers, P., Haines, K., Keene, B., Bauer, J., Pfeiffer, M., McCluskey, J., Settle, J. and Sparks, B. (2006) Toward a Theory of Choice for Community College Students. Community College Journal of Research and Practice, 30, 53-67. http://dx.doi.org/10.1080/10668920500248886

[26] Hossler, D., Schmit, J. and Vesper, N. (1999) Going to College: How Social, Economic, and Educational Factors Influence the Decisions Students Make. Johns Hopkins Press, Baltimore.

[27] Jackson, G. (1982) Public Efficiency and Private Choice in Higher Education. Educational Evaluation and Policy Analysis, 4, 237-247. http://dx.doi.org/10.3102/01623737004002237

[28] Angell, C., Henriksen, E.K. and Isnes, A. (2003) Hvorfor lære fysikk? Det kan andre ta seg av! Fysikkfaget i norsk utdanning: Innhold-oppfatninger-valg [Why Learn Physics? Others Can Take Care of That! Physics in Norwegian Education: Content-Perceptions-Choices]. In: Jorde, D. and Bungum, B., Eds., Naturfagdidaktikk. Perspektiver, forskning, utvikling [Science Education. Perspectives, Research and Development], Gyldendal Akademisk, Oslo, 165-198.

[29] Lindahl, B. (2003) Lust att lära naturvetenskap ock teknik? En longitudinell studie om vägen till gymnasiet [A Desire to Learn Science and Technology? A Longitudinal Study of Pathways to Upper Secondary School]. Unpublished Doctoral thesis, Göteborg Studies in Educational Sciences, Göteborg.

[30] Ramberg, I. (2006) Realfag eller ikke? Elevers motivasjon for valg og bortvalg av realfag i videregående opplæring. NIFU STEP, Oslo. 
[31] Sjödin, U. (2001) Ungdomskultur ock naturvetenskap. Perspektiv från kulturvetenskaplig ungdomsforskning på NOT-projektets målsättning [Youth Culture and Science. Perspectives from Social Sciences and Youth Research on the Aims of the NOT-Project]. Publisher, Stockholm.

[32] IRIS (2009) IRIS-Interest and Recruitment in Science: Factors Influencing Recruitment, Retention and Gender Equity in Science, Technology and Mathematics Higher Education. A Collaborative Project: Science in Society. Seventh Framework Programme. http://iris.fp-7.org/about-iris/

[33] Cerini, B., Murray, I. and Reiss, M.J. (2003) Student Review of the Science Curriculum. Major Findings. Planet Science, Institute of Education, Science Museum, University of London, London.

[34] Kjærnsli, M. and Lie, S. (2000) Kjønnsforskjeller i realfag: Hva kan TIMSS fortelle? [Gender Differences in Science and Mathematics Education: What Can TIMSS Tell Us?]. In: Imsen, G., Ed., Kjønn og likestilling i grunnskolen [Sex and Equity in Primary and Lower Secondary School]. Gyldendal Akademisk, Oslo.

[35] Osborne, J. and Collins, S. (2000) Pupils' and Parents' Views of the School Science Curriculum. Wellcome Trust, King's College London, London.

[36] Osborne, J. and Collins, S. (2001) Pupils' Views of the Role and Value of the Science Curriculum: A Focus-Group Study. International Journal of Science Education, 23, 441-467. http://dx.doi.org/10.1080/09500690010006518

[37] Scantlebury, K. and Baker, D. (2007) Gender Issues in Science Education Research: Remembering Where the Difference Lies. In: Abell, S.K. and Lederman, N.G., Eds., Handbook of Research on Science Education, Routledge, Abingdon.

[38] Schreiner, C. (2006) Exploring a ROSE-Garden: Norwegian Youth’s Orientations towards Science-Seen as Signs of Late Modern Identities. Based on ROSE (The Relevance of Science Education), a Comparative Study of 15 Year Old Students’ Perceptions of Science and Science Education. Unpublished Doctoral thesis, University of Oslo, Oslo.

[39] Brown, M., Brown, P. and Bibby, T. (2008) "I Would Rather Die”: Reasons Given by 16-Year-Olds for Not Continuing Their Study of Mathematics. Research in Mathematics Education, 10, 3-18. http://dx.doi.org/10.1080/14794800801915814

[40] Matthews, A. and Pepper, D. (2007) Evaluation of Participation in GCE Mathematics. Qualifications and Curriculum Authority, London.

[41] Mendick, H. (2006) Masculinities in Mathematics. Open University Press, Buckingham.

[42] Johnson, S.E. (1999) Gender, Identity and Academic Subject Choice at School and University. Unpublished Ph.D. Thesis, Queen's University of Belfast, Belfast.

[43] Jarman, R., McAleese, L. and McConnell, B. (1997) A Survey of Science at Key Stage 4. The Queen’s University of Belfast, Belfast.

[44] Bewick, V. and Southern, J. (1997) Factors Influencing Students' Choice of Mathematics at A-Level. Teaching Mathematics and Its Applications, 16, 74-78. http://dx.doi.org/10.1093/teamat/16.2.74

[45] Gallagher, A., McEwen, A. and Knipe, D. (1996) Girls and A Level Science 1985 to 1995. Equal Opportunities Commission for Northern Ireland, Belfast.

[46] Kjærnsli, M., Lie, S., Olsen, R.V. and Roe, A. (2007) TId for tunge løft. Norske elevers kompetanse i naturfag, lesing og matematikk i PISA 2006. Universitetsforlaget, Oslo.

[47] Häussler, P. and Hoffmann, L. (2000) A Curricular Frame for Physics Education: Development, Comparison with Students' Interests, and Impact on Students' Achievement and Self-Concept. Science Education, 84, 689-705. http://dx.doi.org/10.1002/1098-237X(200011)84:6<689::AID-SCE1>3.0.CO;2-L

[48] Bandura, A., Barbaranelli, C., Caprara, G.V. and Pastorelli, C. (2001) Self-Efficacy Beliefs as Shapers of Children’s Aspirations and Career Trajectories. Child Development, 72, 187-206. http://dx.doi.org/10.1111/1467-8624.00273

[49] Galotti, K.M. and Mark, M.C. (1994) How Do High School Students Structure an Important Life Decision? A ShortTerm Longitudinal Study of the College Decision-Making Process. Research in Higher Education, 35, 589-607. http://dx.doi.org/10.1007/BF02497089

[50] Brown, R.C., Hernandez, M.Y., Mitchell, T.D. and Turner, C.R. (1999) Factors Influencing Student College Choice between In-State and Out-of-State Students. Journal of the Indiana University Student Personnel Association.

[51] Hanson, K. and Litten, L. (1982) Mapping the Road to Academia: A Review of Research on Women, Men, and the College Selection Process. In: Perun, N.P., Ed., The Undergraduate Woman, Issues in Education, Lexington, Lexington.

[52] Spielhofer, T., O’Donnell, L., Benton, T., Schagen, S. and Schagen, I. (2002) The Impact of School Size and SingleSex Education on Performance. National Foundation for Education Research, London.

[53] Croxford, L. (1994) Equal Opportunities in the Secondary-School Curriculum in Scotland, 1977-91. British Educational Research Journal, 20, 371-391. http://dx.doi.org/10.1080/0141192940200402 
[54] Vidal Rodeiro, C.L. (2007) A Level Subject Choice in England: Patterns of Uptake and Factors Affecting Subject Preferences. Cambridge Assessment, Cambridge.

[55] Sharp, C., Hutchison, D., Davis, C. and Keys, W. (1996) The Take-Up of Advanced Mathematics and Science Courses. Schools Curriculum and Assessment Authority, London.

[56] Cheng, Y., Payne, J. and Witherspoon, S. (1995) Science and Mathematics in Full Time Education after 16: The England and Wales Youth Cohort Study. Department for Education and Employment, London.

[57] Farnsworth, V. and Davis, P. (2008) Addressing Economic Inequality through Financial Capability Education: Is there Evidence of Empowerment? American Educational Research Association (AERA) Conference, New York, 24-28 March 2008.

[58] van Dijk, T.A. (1998) Ideology: A Multidisciplinary Approach. Sage Publications, London.

[59] Hossler, D. and Gallagher, K. (1987) Studying Student College Choice: A Three-Phase Model and the Implications for Policymakers. College and University, 62, 207-221.

[60] St. John, E.P. (1990) Price Response in Enrollment Decisions: An Analysis of the High School and beyond Sophomore Cohort. Research in Higher Education, 31, 161-176. http://dx.doi.org/10.1007/BF00992260

[61] St. John, E.P. (1991) The Impact of Student Financial Aid: A Review of Recent Research. Journal of Student Financial Aid, 21, 18-32.

[62] St. John, E.P. and Starkey, J.B. (1995) An Alternative to Net Price: Assessing the Influence of Prices and Subsidies on Within-Year Persistence. Journal of Higher Education, 66, 156-186. http://dx.doi.org/10.2307/2943910

[63] Hayes, T. (1989) How Student Choose a College: A Qualitative Approach. Journal of Marketing for Higher Education, 2, 19-28. http://dx.doi.org/10.1300/J050v02n01_04

[64] Joseph, M. and Joseph, B. (2000) Indonesian Students' Perceptions of Choice Criteria in the Selection of a Tertiary Institution: Strategic Implications. International Journal of Educational Management, 14, 40-44. http://dx.doi.org/10.1108/09513540010310396

[65] Mazzarol, T. and Soutar, G. (2002) Push-Pull Factors Influencing International Students Destination Choice. International Journal of Educational Management, 16, 82-90. http://dx.doi.org/10.1108/09513540210418403

[66] Water, D., Abrahamson, T. and Lyons, K. (2009) High-Achieving Seniors and the College Decision, Lipman Hearne Key Insights. http://www.lipmanhearne.com/home.aspx

[67] Lee, S.J. and Chatfield, H.K. (n.d.) The Analysis of Factors Affecting Choice of College: A Case Study of UNLV Hotel College Students.

http://ccs.infospace.com/ClickHandler.ashx?du=scholarworks.umass.edu\%2fcgi\%2fviewcontent.cgi\%3farticle\%3d128 8\%26...\&ru=http\%3a\%2f\%2fscholarworks.umass.edu\%2fcgi\%2fviewcontent.cgi\%3farticle\%3d1288\%26context\%3dg rad-

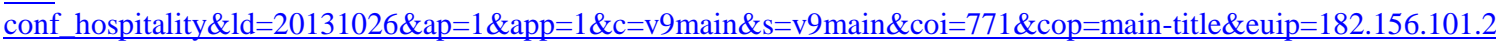
48\&npp=1\&p=0\&pp=0\&pvaid=abf3a6828eb6403baf20617c7cc25403\&ep=1\&mid=9\&en=6HWE5j\%2fygPrVeymkB muviIeZqrsBQFVUf28T\%2bj92oiI\%3d\&hash=79A046C61516338E8114345DF8F37B9E

[68] Niu, S.X. and Tienda, M. (2008) Choosing College: Identifying and Modeling Choice Sets. Social Science Research, 37, 416-433. http://dx.doi.org/10.1016/j.ssresearch.2007.06.015

[69] NSSO (2010) Education in India, 2007-08: Participation and Expenditure. NSS Report No. 532. National Sample Survey Office, National Statistical Organisation, Ministry of Statistics and Programme Implementation, Government of India, New Delhi.

[70] Chitnis, S. (1997) Definition of the Terms Scheduled Castes and Scheduled Tribes: A Crisis of Ambivalence. In: Panandiker, V.A.P., Ed., The Politics of Backwardness: Reservation Policy in India, Centre for Policy Research, New Delhi.

[71] Deaton, A. and Dreze, J. (2002) Poverty and Inequality in India: A Re-Examination. Economic and Political Weekly, 37, 3729-3748.

[72] Murthy, K.N. (2001) Effects of Changes in Household Size, Consumer Taste and Preferences on Demand Pattern in India. Working Paper No. 72, Center for Development Economics, Delhi School of Economics, Delhi.

[73] Bhagat, R.B. (2005) Rural-Urban Classification and Municipal Governance in India. Singapore Journal of Tropical Geography, 26, 61-73. http://dx.doi.org/10.1111/j.0129-7619.2005.00204.x

[74] IIPS, Macro International (2007) National Family Health Survey India, 2005-06 NFHS-3. International Institute for Population Sciences, Mumbai.

[75] Rao, J.N.K. and Scott, A.J. (1984) On Chi-Square Tests for Multiway Contingency Tables with Cell Proportions Estimated from Survey Data. Annals of Statistics, 12, 46-60. http://dx.doi.org/10.1214/aos/1176346391

[76] Warner, R.M. (2008) Applied Statistics: From Bivariate through Multivariate Techniques. Sage Publications, Califor- 
nia.

[77] Chan, Y.H. (2005) Biostatistics 305. Multinomial Logistic Regression. Singapore Medical Journal, 46, 259-268.

[78] Hosmer, D.W. and Lemeshow, S. (1989) Applied Logistic Regression. Wiley \& Sons, New York.

[79] Retherford, R.D. and Choe, M.K. (1993) Statistical Models for Causal Analysis. John Wiley and Sons, New York. http://dx.doi.org/10.1002/9781118033135

[80] Statacorp (2007) Stata Statistical Software: Release 10. Statacorp LP, College Station, TX.

[81] Pollard, E., Jagger, N., Perryman, S., Van Gent, M. and Mann, K. (2003) Ready, SET Go: A Review of SET Study and Career Choices (Technical Report). Engineering Technology Board, London.

[82] Murphy, P. and Whitelegg, E. (2006) Girls in the Physics Classroom: A Review of the Research on the Participation of Girls in Physics (Technical Report). Institute of Physics, London.

[83] Tripney, J., Newman, M., Bangpan, M., Niza, C., MacKintosh, M. and Sinclair, J. (2010) Factors Influencing Young People (Aged 14-19) in Education about STEM Subject Choices: A Systematic Review of the UK Literature. Evidence for Policy and Practice Information and Co-Ordinating Centre, Institute of Education, University of London, London.

[84] Osborne, J., Simon, S. and Collins, S. (2003) Attitudes towards Science: A Review of the Literature and Its Implications. International Journal of Science Education, 25, 1049-1079. http://dx.doi.org/10.1080/0950069032000032199

[85] Gorard, S. (2008) The Impact of SES on Participation and Attainment in Science: A Review of Existing Literature. In: The Royal Society, Ed., Exploring the Relationship between Socioeconomic Status and Participation and Attainment in Science Education, The Royal Society, London.

[86] Warrington, M. and Younger, M. (2000) The Other Side of the Gender Gap. Gender and Education, 12, 493-508. http://dx.doi.org/10.1080/09540250020004126

[87] Filmer, D., King, E. and Pritchett, L. (1998) Gender Disparity in South Asia, Comparisons between and within Countries. World Bank Policy Research Working Paper No. 1867, place of publication.

[88] Alderman, H. and King, E.M. (1998) Gender Differences in Parental Investment in Education. Structural Change and Economic Dynamics, 9, 453-468. http://dx.doi.org/10.1016/S0954-349X(98)00040-X

[89] Clarke, D., Shimizu, Y., Ulep, S.A., Gallos, F.L., Sethole, G., Adler, J. and Vithal, R. (2006) Cultural Diversity and the Learner's Perspective: Attending to Voice and Context. In: Leung, F.K., Graf, K.D. and Lopez, F.J., Eds., Mathematics Education in Different Cultural Traditions-A Comparative Study of East Asia and the West, Springer, New York, 353-380. http://dx.doi.org/10.1007/0-387-29723-5_20

[90] Van de Werfhorst, H.G., De Graaf, N.D. and Kraaykamp, G. (2001) Intergenerational Resemblance of Field of Study in the Netherlands. European Sociological Review, 17, 275-293. http://dx.doi.org/10.1093/esr/17.3.275

[91] Dryler, H. (1998) Parental Role Models, Gender, and Educational Choice. British Journal of Sociology, 49, $375-398$. http://dx.doi.org/10.2307/591389

[92] Davies, S. and Guppy, N. (1997) Fields of Study, College Selectivity, and Student Inequalities in Higher Education. Social Forces, 75, 1417-1438. http://dx.doi.org/10.1093/sf/75.4.1417

[93] Hansen, M.N. (1997) Social and Economic Inequality in the Educational Career: Do the Effects of Social Background Characteristics Decline? European Sociological Review, 13, 305-321. http://dx.doi.org/10.1093/oxfordjournals.esr.a018220

[94] Van de Werfhorst, H.G., Sullivan, A. and Cheung, S.Y. (2003) Social Class, Ability and Choice of Subject in Secondary and Tertiary Education in Britain. British Educational Research Journal, 29, 41-62. http://dx.doi.org/10.1080/0141192032000057366

[95] Welch, A. (2007) Cultural Difference and Identity. In: Connell, R., Campbell, C., Vickers, M., Welch, A., Foley, D. and Bagnall, N., Eds., Education, Change and Society, Oxford University Press, Melbourne, 155-187.

[96] Cao, Z.J., Bishop, A.J. and Forgasz, H. (2006) Perceived Parental Influence on Mathematics Learning: A Comparsion among Students in China and Australia. Educational Studies in Mathematics, 64, 85-106. http://dx.doi.org/10.1007/s10649-006-9033-5

[97] McPhan, G., Morony, W., Pegg, J., Cooksey, R. and Lynch, T. (2008) Maths? Why Not? Department of Education, Employment and Workplace Relations, Canberra.

[98] Bardell, G. (1982) Options for the Fourth: The Report of an Explanatory Study in Ten Schools. Schools Council, London.

[99] Kelsall, R.K., Poole, A. and Kuhn, A. (1972) Graduates: The Sociology of an Elite. Methuen, London.

[100] Boudon, R. (1974) Education, Opportunity and Social Inequality. Wiley, New York.

[101] Becker, G. (1975) Human Capital. Chicago University Press, Chicago. 
[102] Bratti, M. (2006) Social Class and Undergraduate Degree Subject in the UK. IZA Discussion Paper No. 1979, The Institute for the Study of Labor, Bonn.

[103] Bedard, K. and Dhuey, E. (2006) The Persistence of Early Childhood Maturity: International Evidence of Long-Run Age Effects. Quarterly Journal of Economics, 121, 1437-1472.

[104] Currie, J. (2001) Early Childhood Education Programs. Journal of Economic Perspectives, 15, 213-238. http://dx.doi.org/10.1257/jep.15.2.213

[105] Angrist, J.D. and Krueger, A.B. (1992) The Effect of Age at School Entry on Educational Attainment: An Application of Instrumental Variables with Moments from Two Samples. Journal of the American Statistical Association, 87, 328336. http://dx.doi.org/10.1080/01621459.1992.10475212

[106] GoI (2009) Annual Report 2008-09. Ministry of Labour and Employment, Government of India, New Delhi.

[107] Roberts, G. (2002) SET for Success. The Supply of People with Science, Technology, Engineering and Mathematics Skills. HM Treasury, London.

[108] Smith, A. (2004) Making Mathematics Count. The Report of Professor Adrian Smith’s Inquiry into Post-14 Mathematics Education. HMSO, London.

[109] Atweh, B., Taylor, S. and Singh, P. (2005) School Curriculum as Cultural Commodity in the Construction of Young People’s Post-School Aspirations. In: Proceedings Australian Association for Research in Education, University of Western Sydney, Parramatta. http://eprints.qut.edu.au

[110] Knight, B. (2004) Vocational Learning in Schools as an Equity Strategy. In: Bowman, K., Ed., Equity in Vocational Education and Training: Research Readings, NCVER, Adelaide, 194-205.

[111] Polesel, J., Helme, S., Davies, M., Teese, R., Nicholas, T. and Vickers, M. (2004) VET in Schools. A Post-Compulsory Education Perspective. NCVER, Adelaide.

[112] Patton, W. and McCrindle, A. (2001) Senior Students’ Views on Career Information: What Was the Most Useful and What Would They Like? Australian Journal of Career Development, 10, 32-36. http://dx.doi.org/10.1177/103841620101000108

[113] Whiteley, S. and Neil, C. (2000) Queensland Year 12 Experiences of Access to Information about Post School Options: Are There Equity Issues? Tertiary Entrance Procedures Authority. www.qsa.qld.edu.au/downloads/.../research_tepa_equity_00.pdf

[114] Singh, A. (1999) Educational Imbalance in India: Transition from School to College. Economic and Political Weekly, 34, 1675-1679. 


\section{Appendix 1}

Table A1. Analytic sample (population aged $\leq 29$ years currently attending educational institution) used for the multivariate analysis by selected covariates, NSS (2007-08).

\begin{tabular}{|c|c|c|c|c|c|}
\hline Covariates & $\%$ & $\mathrm{n}$ & Covariates & $\%$ & $\mathrm{n}$ \\
\hline Sex & & & Medium of instruction & & \\
\hline Male & 57.9 & 6420 & English & 35.5 & 4949 \\
\hline Female & 42.1 & 5031 & Hindi & 33.9 & 3279 \\
\hline Age at entry in school & & & Others & 30.6 & 3221 \\
\hline$\leq 5$ & 68.1 & 7559 & Status of free education & & \\
\hline$\geq 6$ & 31.9 & 3892 & Free & 23.7 & 2867 \\
\hline Father's education level & & & Partially exempted & 2.3 & 235 \\
\hline Not literate & 13.3 & 1194 & Neither free nor exempted & 74.0 & 8349 \\
\hline Below Primary & 7.1 & 743 & Scholarship received & & \\
\hline Primary & 12.0 & 1160 & Yes & 11.2 & 1458 \\
\hline Middle & 19.1 & 1965 & No & 88.8 & 9993 \\
\hline Secondary \& Higher & 48.6 & 5291 & Books/stationery received ${ }^{a}$ & & \\
\hline Mother's education level & & & Yes & 1.3 & 173 \\
\hline Not literate & 31.9 & 3130 & No & 98.7 & 11,276 \\
\hline Below Primary & 8.5 & 953 & Distance of institution & & \\
\hline Primary & 15.9 & 1707 & $1-2 \mathrm{~km}$ & 28.8 & 3859 \\
\hline Middle & 17.3 & 2007 & $>2 \mathrm{~km}$ & 71.2 & 7556 \\
\hline Secondary \& Higher & 26.4 & 3349 & Mode of transport & & \\
\hline Social group & & & On foot & 25.5 & 3215 \\
\hline ST & 4.1 & 936 & School/Public Vehicle with no concession & 18.2 & 2033 \\
\hline SC & 15.1 & 1525 & Public Vehicle with concession & 24.2 & 2343 \\
\hline Others & 80.8 & 8990 & Bicycle/Others & 32.1 & 3257 \\
\hline Religion & & & MPCE $E^{\mathrm{b}}$ quintile & & \\
\hline Hindu & 84.1 & 9071 & Q1 & 6.5 & 564 \\
\hline Islam & 9.5 & 1133 & Q2 & 11.8 & 1090 \\
\hline Christian & 2.9 & 723 & Q3 & 17.6 & 1814 \\
\hline Others & 3.6 & 524 & Q4 & 22.2 & 2594 \\
\hline Household size & & & Q5 & 41.9 & 5389 \\
\hline$\leq 5$ & 65.7 & 7601 & Type of residence & & \\
\hline $6-9$ & 29.6 & 3385 & Rural & 56.4 & 5208 \\
\hline$\geq 10$ & 4.7 & 465 & Urban & 43.6 & 6243 \\
\hline Sibling composition & & & Region of residence & & \\
\hline Only Son & 7.7 & 883 & North & 15.2 & 2069 \\
\hline
\end{tabular}




\section{Continued}

\begin{tabular}{|c|c|c|c|c|c|}
\hline Only daughter & 4.5 & 535 & Central & 23.4 & 1855 \\
\hline 1 brother, 1 sister & 17.4 & 2046 & East & 12.4 & 1459 \\
\hline $1+$ brother, no sister & 16.4 & 1817 & West & 17.2 & 1793 \\
\hline $1+$ brother, 1 sister & 19.3 & 2118 & South & 28.7 & 2891 \\
\hline $1+$ brother, $1+$ sister & 14.6 & 1594 & Northeast & 2.7 & 1,091 \\
\hline Other mixed composition & 20.2 & 2458 & Island/UTs & 0.5 & 293 \\
\hline \multicolumn{6}{|l|}{ Type of institution } \\
\hline Govt./Public & 51.2 & 6220 & & & \\
\hline Private & 48.8 & 5101 & & & \\
\hline
\end{tabular}

${ }^{\mathrm{a}}$ For free or at subsidized rate; ${ }^{\mathrm{b}}$ Monthly Per Capita Expenditure; "n” represents unweighted sample cases. Note: Proportions (\%) are weighted. All covariates were significantly different at $p<0.001$, except the variable "Books/stationary received" $(p=0.003)$ in the $\chi^{2}$ test applied with the outcome variable. 